\title{
THE REUSE OF INDUSTRIAL TANNERIES. ARCHITECTURAL HERITAGE IN GUIMARÂES, PORTUGAL
}

\author{
K. González Vargas ${ }^{1,}$ * \\ ${ }^{1}$ PhD School Doctoral Program Degree in Architecture, Building, Urban Planning and Landscape (2214), \\ Universitat Politècnica de València, Valencia, Spain - katherinegonzalezdis@gmail.com
}

\author{
Commission II - WG II/8
}

KEY WORDS: Tanneries, Industrial Heritage, Rehabilitation, Re-use sustainability

\begin{abstract}
:
The city of Guimarâes (Portugal) was designated a UNESCO World Heritage Site in 2001 and European Capital of Culture in 2012. From the 14th to the 19th century it was characterized by its Portuguese architecture using traditional construction techniques and materials, and known for its leather, metallurgical and cutlery industry. This study examines two former tannery factories dating from the 19th century, and occupying a sizeable portion of the historic centre of the city. They are located close to the Couros river, their main source of water, but also where the tannery waste produced by the tanks where the skins were tanned, is deposited. This text focuses on three main concepts - rehabilitation, reuse and sustainability - through the analysis of two historical moments. The first of these, the past, is viewed through a timeline of events recorded in plans, photographs, documents, and historical facts. A formal spatial comparison of these records and the present buildings shows how the present use of these spaces and their respective functionalities can be observed in parallel with the past. This before and after comparison shows a progression from industrial activities to a cultural valorization of an architectural, urban and environmental space, as well as the development of the industry in a new context evoking the collective memory of the place.
\end{abstract}

\section{INTRODUCTION}

\subsection{About reuse of Industrial Heritage}

The perspective of patrimonial inheritance linking territory and abandoned industrial zones and factories, and viewing buildings or heritage assets as physical mediums of initiatives creating new value and use, is of great importance.

The performance of these buildings is complemented with regeneration and rehabilitation for the purposes of production. Historical industrial heritage has thus become a means to stimulate economic activity and create employment.

The main aim of this text is to contribute to the revalorization of an asset of cultural interest seen as part of the fabric of a historical period with major changes in the society and economy of a specific location. Equally, the sectors most affected by devastating economic crises are the regions where steel and coal have traditionally been extracted, and where occasionally initiatives have led to these sites being transformed into museums, eco-museums and other venues to revalorize what remains of the industry.

In Europe, the largest concentration of industry was located in Wales, predominantly coal and steel in the south and slate in the north. The transport of these goods also contributed to a strong maritime industry. Coal was also exported from many different traditionally mining regions in Europe: Wallonia, MonsCharleroi, or Calais. In fact, northern Calais was a landscape of over 12,000 ha, formed over three centuries of coal extraction from the 18th to the 20th century. The oldest mining pit dates from 1850. Furthermore, according to (Meissner, 1993) the Ruhr region can be considered one of the most industrialized regions both in Europe and worldwide as it was the industrial heart of Europe in the mid-20th century, accounting for much of the coal ore and the iron and steel industry of this area of Germany. Over time, many of these factories closed and became obsolete. In the specific case of Portugal, in order to avoid further deterioration, a process of recovery and rehabilitation of former factories and abandoned land was launched to serve as a basis for new spaces for production. The development of the industry over the last two hundred years in Portugal, where the industrial revolution took place slowly and late, cannot be compared with that of countries which were industrialized from the early 19th century.

In fact, for most of its history, Portugal was a country where, until after World War II, activities relating to agriculture, fishing and commerce were more important than industry.

Although its economy lagged behind, modern industry was widely known in Portugal from very early on. As far back as the 18th century the country tried to keep abreast of modern European industrialization, setting up the first modern factories specializing in cotton yarn by the end of the 18th century. (Del Pozo, 2014)

\subsection{Reuse in Portugal}

Research by José Manuel Lopes Cordeiro includes a classification of the main industrial heritage of Portugal and its location until 1998. In 1819 the steam engine arrived in Portugal. In inland regions electrical energy was a major energy resource during the 19th century and the first decades of the 20th century. 1850 and 1914 saw a progressive increase in industrial development, while interest in industrial archaeology grew increasingly from 1870 against the backdrop of a larger movement for the defence of national cultural heritage. The main initiatives focused on industrial heritage were carried out

\footnotetext{
* Corresponding author
} 
in the 1980s, including the reuse of an old out-of-service thermoelectric plant in Lisbon, "La Central Tejo", now the electricity museum, where an exhibition was organized. The following year the "National Meeting on Industrial Heritage" was held in the city of Guimarâes. The Portuguese government has produced a classification of factories and industrial structures, with Lisbon heading the list in terms of the number of classified industries. These include Estaçao Ferroviaria do Rossio, classified in 1971 (Figure 1), and the Viúva Lamego ceramic factory, classified in 1978.

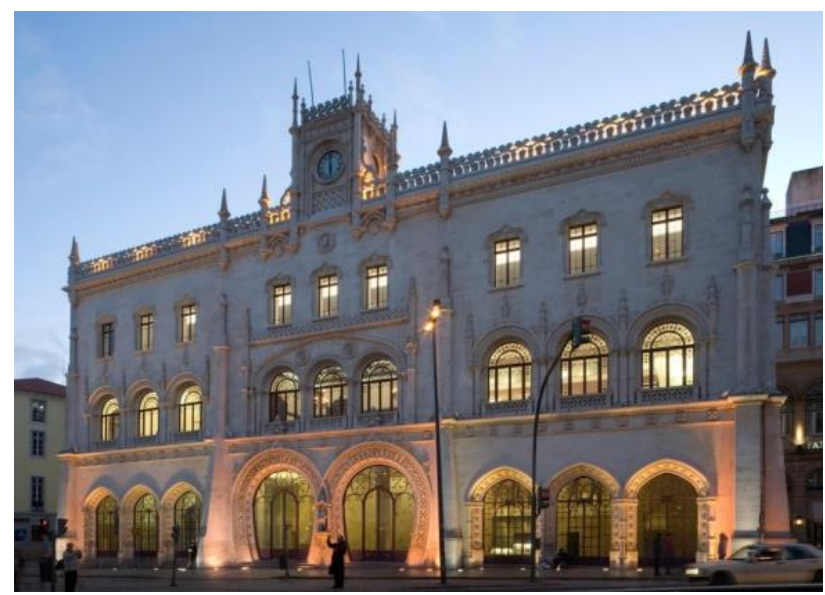

Figure 1. Estaçao Ferroviaria do Rossio,

Architects: José Luís Monteiro (1887) Broadway Malyan

(2006) Source: Open House Lisboa

This list also includes Grandela, an early 20th-century neighbourhood built for workers' housing, and Garagem AutoPalace and Fabrica das Sedas, both of which were added in 1984. More recent classifications include Fabrica Nacional de Cordoaria, Fabrica Standar Eléctrica and Vila Berta, workers' housing in the capital.

Of the structures classified in Porto the most important are the two 19th-century iron bridges: the Luis I railway and road bridge and the D. Maria Pia railway bridge, which is currently out of service and has been classified as a national monument since 1982 .

In 1998, industrial buildings began to be reused in Portugal, as in the case of the Jerónimo Pereira Santos Ceramic Factory, founded in Aveiro in 1896 and used to produce bricks and tiles in the Marseille style. It is now a professional school and cultural centre, and although much of the interior was demolished, its facades and one of the chimneys were preserved.

Also in Porto, the Museu do Carro Elétrico is housed in an old tram station built in 1915, while in various regions of Portugal different types of industrial buildings are being reused. In the case of Guimarâes, the former tannery factories which are still standing and some leather tanks have been restored as vital evidence of the presence of the tannery industry there (Cordeiro, 1998).

\subsection{Industrial heritage in Guimarâes}

This study focuses on the industrial heritage of tanneries in the city of Guimarâes, Portugal, extremely important at different points in history and part of its cultural and heritage legacy (Pereira, 2009)
Some industrial and heritage buildings have been rehabilitated to generate new uses and a new identity without losing their historical features. This industrial nucleus has remained close to the river Couros and was practically integrated into the city centre from as early as the 17th century. However, the tannery industry also developed in the rural areas of the municipality of Guimarâes and neighbouring municipalities.

It would also be remiss not to mention the serious health hazards involved in the tanning process, which led to the spread of pollution throughout the city (Domingues, 2011).

Guimâraes is also a city which has managed to maintain its original structure thanks to the use of traditional construction materials. However, the restoration and rehabilitation of the historic urban centre and the subsequent evolution of Guimâraes is leading to the gradual abandonment of heritage houses because of their large size and the lack of funds for interventions. The policies of urban development and intervention include rehabilitation measures, among which it is worth noting the requalification of the city as a way of optimizing resources; a new development model which takes cultural, environmental and social economic factors into account; finding ways to rehabilitate heritage buildings focusing on safeguarding, conservation and rehabilitation; and the implementation of new forms of action which allow and promote responsibilities. The issue of the rehabilitation of the historic centre has become a matter for political concern.

Since 1849, national and international conventions have emerged. In 1999, an urban requalification programme took into consideration that urban and building rehabilitation cannot occur without each other, as they are inextricably linked. It was in 2010 that treaties for environmental protection and for the conservation of architectural heritage were defined. Additionally, the historic centre of Guimâraes is intimately linked to Portuguese self-identity, preserving a series of historical constructions that show the evolution of the different types of Portuguese buildings. However, from the Middle Ages to the mid-1890s there was a progressive physical and social deterioration of the place which was impossible to prevent. In 1985, a municipal office was created for the administration of the historic centre. This project aimed to improve habitability and preserve the authenticity of this heritage site; the centre of Guimarâes should not be a closed place but a connected community taking advantage of its own potential. In 1995, the historic centre of Guimâraes was nominated to become part of the UNESCO Cultural Heritage of Humanity (Pereira, 2012).

There are elements of great patrimonial value to be found in Guimarâes. One of these is Countess Mumadona's castle, built for her in the 10th century as protection from Norman attacks. This is also close to the historical site of the Battle of São Mamede (1128), a defining event thanks to which Portugal was able to become an independent kingdom. Restoration work on the castle was completed in 1940, coinciding with the celebration of the Eighth Centenary of Portugal's Independence. (Domingues, Matos, 2011).

The industrial activity of Guimarâes, defined as a city of great economic wealth and outstanding in the production of leather, cutlery and metallurgy, is home to some of Portugal's most reputed brands. Many of the most important events in the city's timeline are connected with its industry. 
According to documents, in 1151 there were tannery workers' homes in Guimarães. In 1814, according to (Neves, J. A, das 1814) there were 86 tanneries registered throughout the Guimarães Region (Figure 2), and by 1862, 41 of these produced about 300,000 kilos of tanned hides and prepared them for export. Between 1863 and 1864, in the text by De Sousa Pinto (2012), «Homens de Couros»: «marcas no presente do passado da indústria de curtumes em Guimarães, Tannery workers», brands in the tannery industry in Guimarães were responsible for the waste, gases and pollution deposited in the river Couros, a small river with a low flow, by tannery factories classified as unhealthy industries. In 1915, there were at least 15 such factories, located on Rua de Couros and in 1921, the construction of 20 tanning tanks was authorised "num seu campo, sito nas traseiras duns prédios da Rua da Ramada" ("in your field, located behind the buildings on Rua da Ramada Ramada"). The António Martins Ribeiro da Silva factory building, founded in the 1930s, stood on Rua da Ramada and was therefore known as the Ramada Factory. In 1977, the General Directorate for Cultural Heritage classified the Couros Area as a property of public interest, and gradually, most of these tanneries ceased activity during the 1970s. The pelame ${ }^{l}$ tanks and mills were closed to create a uniform floor where drums were installed to accelerate the tanning process. However, this chemical process caused even more pollution. After it closed in 2005 the Ramada Factory was acquired by the Municipal Chamber of Guimarães and rehabilitated to become the Design Institute of the University of Minho. In 2009, the building was repurposed and rehabilitated as an advanced training centre by the Pitagoras Group architecture firm. In 2012 the former Fabrica da Ramada was rehabilitated as part of Guimarães' designation as a European Capital of Culture, promoted by the City Council.

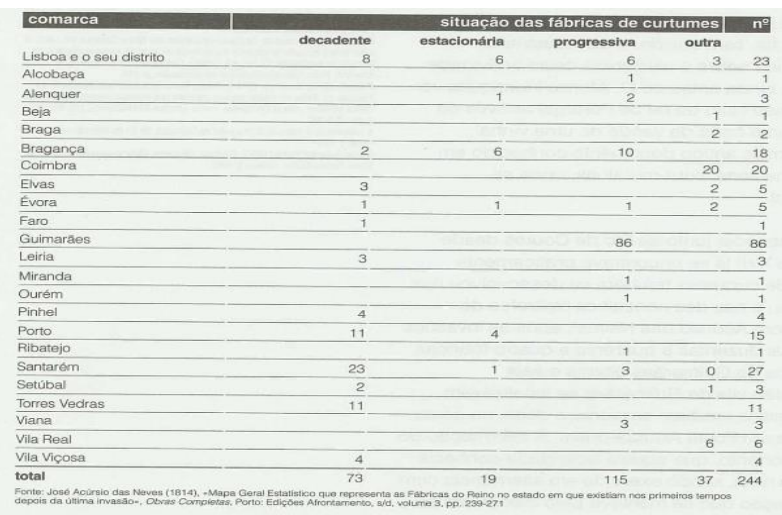

Figure 2. General Statistical Map showing the factories of the kingdom after the first invasion. (Neves, J. A, das 1814). Source: Obras completas Porto: Ediçoes Afrontamento, s/d, Volume 3, pp 258-261.

In the leather industry, workers required a certain degree of specialization and physical strength in order to be able to successfully complete tasks and skilfully handle tools and hides. This made them a respected group within the city.

The training of these men began in adolescence, when they accompanied tanners as helpers. They later gained the status of tanner's apprentice, which lasted for approximately 4 years. The official recognition took place once the worker was able to place the first hide on the board without assistance, and clean the fur and meat. The art of pounding, however, was much more specialized, so few could master it.

1 Pelame: Operation in which the animals' piles are immersed in water and lime to remove the skin.
When their skills were recognized by their peers, they were considered to have entered the trade, an occasion marked by having to pay dinner for the other workers and the boss.

At different moments in political history in Guimarães we see "the artists of the Rua de Couros" taking sides with one of the factions, sometimes even violently defending their convictions. They led strikes, demanded better working conditions, achieved wage increases, constituting a cohesive, conservative and tough working class.

\subsection{Objectives}

The main objectives of this study are

1. To categorize the tannery industrial heritage in Guimarâes through the actions carried out in these areas, based on their most relevant new uses and their relationship with the immediate surroundings.

2. To show how the rehabilitation of the industrial heritage creates meaning in collective memory, in social fabric, and identity of the territory.

3. To reconstruct the collective imagery through the reuse and rehabilitation of the former tannery factories using mapping, graphics and images.

\subsection{Methodology}

A spatial study of the tannery industrial heritage location was carried out, based on prior selection, data collection, and analysis.

Two tannery factories were considered as major points of reference, reviewing similarities and differences in terms of type, location and current property use.

The respective actions on these buildings were reviewed in relation to past and present.

Analysis sheets are based on parameters where the elements are linked in order to understand the building's use and function.

\section{RESILIENCE OF THE INDUSTRIAL HERITAGE}

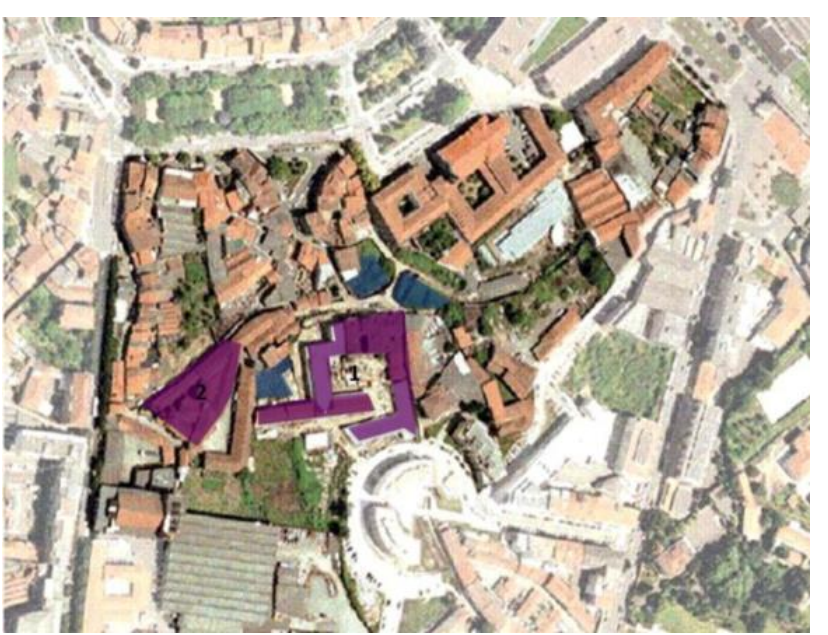

Figure 3. Aerial photograph of the Couros area, Guimarâes (Portugal). Source: drawing by the author using image from Google maps 
In order to examine the actions for improving the resilience of industrial heritage, two old tannery industry buildings have been studied:

\subsection{Case study 1. Before, The former Casal dos Pelames After, Multifunctional Couros Complex}

This was the first factory to be rehabilitated in the Couros area, with a positive effect on the social and cultural aspects of its (Figure 4) environment, although problems were also encountered during the process.

The factories of Miranda, Ferreira and Carvalho once stood in this area. In the 20th century these tanneries ceased their activity and a period of building rehabilitations followed. The initial rehabilitation of one of these into a textile factory in 1999 was followed by Fraterna, built as part of an initiative from the Municipal Chamber of Guimarães in collaboration with a group of public bodies, to serve the most vulnerable members of the community, housing both a kindergarten and a centre for the elderly. In 2001 the rehabilitation of the tannery complex was completed and in 2002, under the name of "Multifunctional Couros Complex", it opened its doors as a social initiative which was warmly welcomed by the public.

This was the result of the combined efforts of small manufacturers who worked independently in this factory. Along with the contemporary architectural language, it is an example of the philosophy of rehabilitation. The structure of the factory is rather irregular and differs from others in the tannery area. Its age can be inferred from this and it still shows the marks of the pre-industrial exploitation practices of these tanks, which had different owners and were often rented out individually to the men of Couros. The largest set of tanks in the entire area can be found around the buildings, looking south. This was the site of 3 factories: the upper one, the lower one, and a newer factory which combined totalled 103 tanning presses 1F, 22 hair tanks, 5 oak bark warehouses, 1 swimming pool, 2 water tanks, and various huts for drying and treating leather. This was transformed into leather following a series of operations known as "river works" (PINTO, M. E. S., 2002).

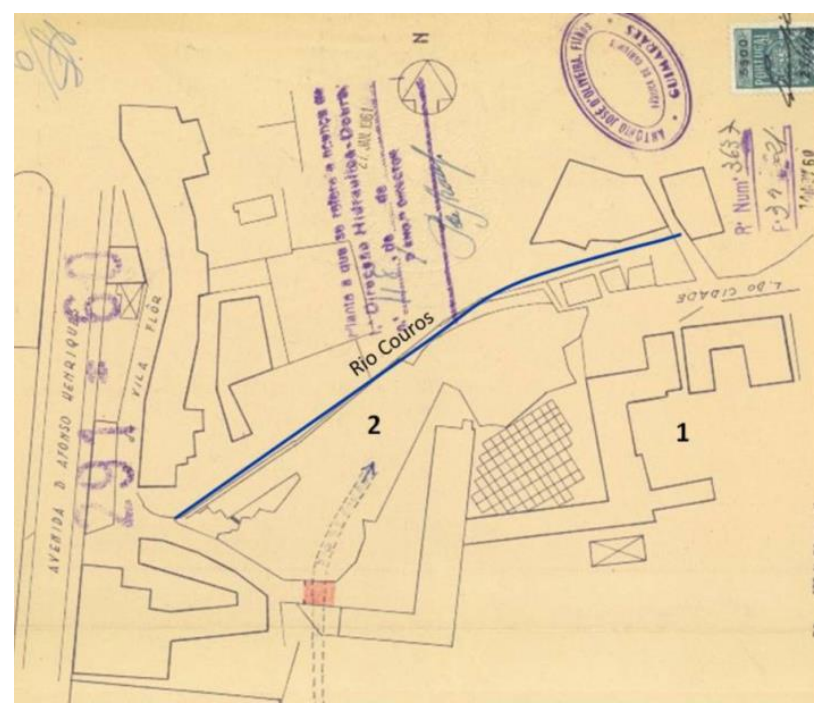

Figure 4. Urban site plan, 1960.

Source: Casa de Sarmento, Arquivo da Agência Portuguesa do Ambiente ARH do Norte, Processo de Obras n. ${ }^{\circ}$ 291-1960 fl.6.

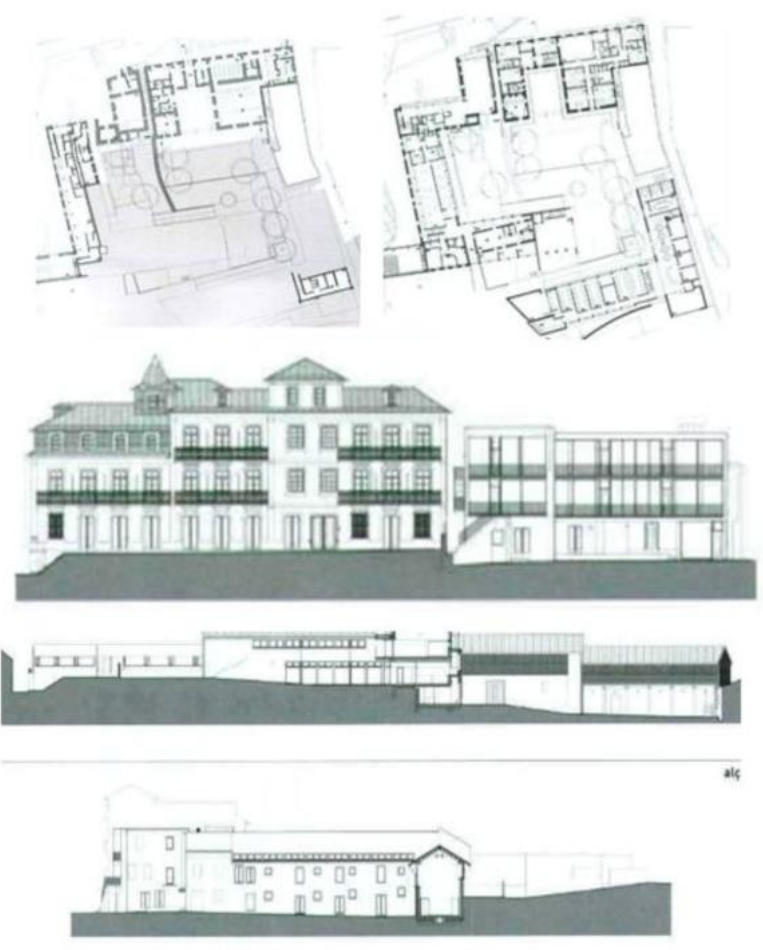

Figure 5. Architectural plans for the former Casal dos Pelames together with the new spatial proposal Source: Revista Arquitectura \& Vida 01-02-2007, p. 39.

This entire area assumed multifunctional characteristics, and wooden platforms were often placed on the tanks, while the slow tanning process was carried out. In the open air, this makeshift platform was used for other operations, such as drying oak bark or extracting hairs and fats which later had other uses.

The old drying quarters were rehabilitated, serving as a reminder of a very common practice during the industrial heyday: the disorderly construction of sheds to create natural airing areas where the hides were left to dry in the open air.

Following the course of the river that flows under the houses built on granite pillars, the old mill house which took advantage of the driving force of the water to propel the millstones can also be seen. The river runs along the alley that leads to Rua de Vila Flor.

2.2 Case study 2. Before, former António José de Oliveira e Filhos factory. After, currently Centre for Advanced Postgraduate Formation, Universidad do Minho.

This building, originally used for the leather industry (Figure 6 ), changed its function to the textile industry in the second half of the 20th century. Nowadays, there are still tangible fragments of the leather treatment tanks where the skins were washed and coloured, and there are several in the area surviving from different factories in the past (Figure 7).

The building's architecture is a reflection of the industrial transformation which has taken place in this part of the city, where the presence of the chimney (Figure 18) and the boiler contrasts with the wooden slat constructions or with the tanks that frame the river's underground course. 
For centuries, and until the first half of the 19th century, the ancient industry of tanneries conserved empirical and archaic practices. However, faced with legal health requirements and technological modernization, some of the leather manufacturers switched their activity to the new textile industry, which was cleaner, with a more immediate return on investment and cheaper labour.

In the rehabilitation of this factory, cleaning and reuse actions were carried out on the interior and exterior stone walls. The number of levels was increased along with the use of new materials, emphasizing the colour red symbolizing the blood of animals and contrasting past and present.

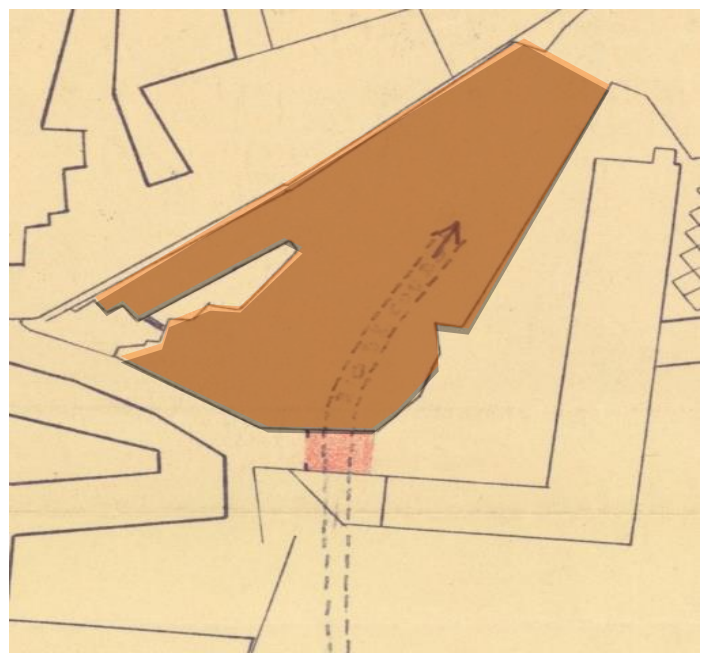

Figure 6. Map showing site limits and persistent morphology 1960. Source: Casa de Sarmento, Arquivo da Agência Portuguesa do Ambiente ARH do Norte, Processo de Obras n. ${ }^{\circ}$ 291-1960 fl.6.

Architect: Unknown, Date (1784)

Surface area: $3,346 \mathrm{~m}^{2}$

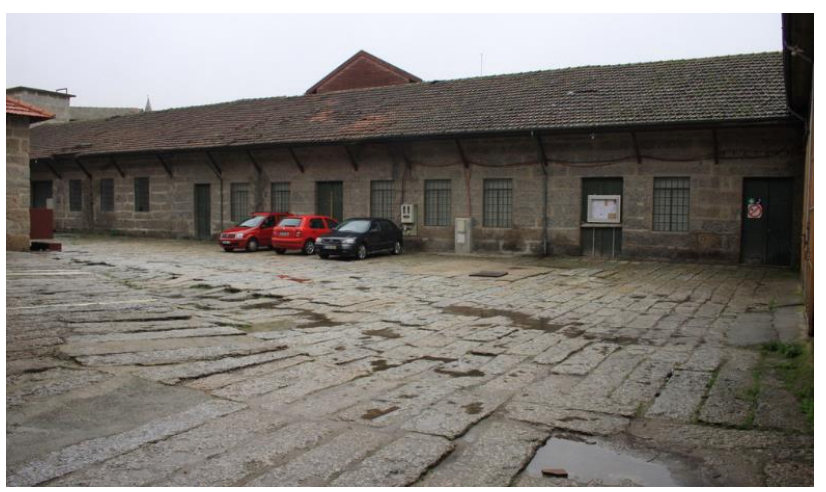

Figure 7. Former Factory António José de Oliveira e Filhos Source: Archive of Guimarâes turismo.

\subsection{Case study 1}

This case study focuses on a complex consisting of several factories, clearly positioned in relation to the leather tanks (Figure 8). The entire central movement starts from these, but this analysis also shows the existence of a high-rise dwelling on the site of the current cyber centre. The foundations of the factories are also located in the heart of the city.

At present there are four spaces of vital importance to the city.
1. Student Residence: This location, with 72 beds, offers accommodation for students who come to the city.

2. Youth centre: multifunctional space for recreation.

3. Fraterna Communication and Social Solidarity Centre: Day centre, incorporating kindergarten facilities for children and offering training courses for older adults. Couros Multifunctional Auditorium also offers different types of screenings, seminars and courses.

4. Guimarâes Association Cyber-centre: this site offers computer facilities and is used by researchers, as well as hosting a study centre, exhibitions, and being used as a base where different initiatives are developed. (Figure 6)

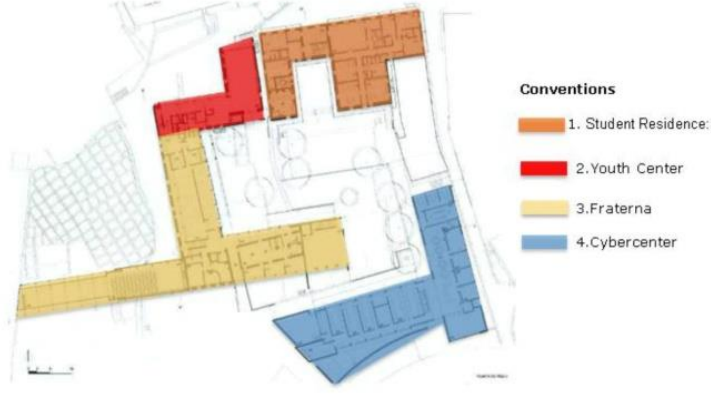

Figure 8. Architectural plans, first floor plan Area: $3679 \mathrm{~m}^{2}$. 4 levels, Year of Realization: 2001/2003, FDO - Construções,

After, Multifunctional Couros Complex. Source: Revista

Arquitectura \& Vida 01-02-2007, P, 36.

The images below (Figure 9) show the extent of the conservation of Casal dos Pelames on the facade of the

student residence. In the foreground a series of tanks that were rented out to different factories can be seen. The following pictures of Fraterna (Figures 10 and 11) show the contrast of the old and the new together with the materiality of the stone.

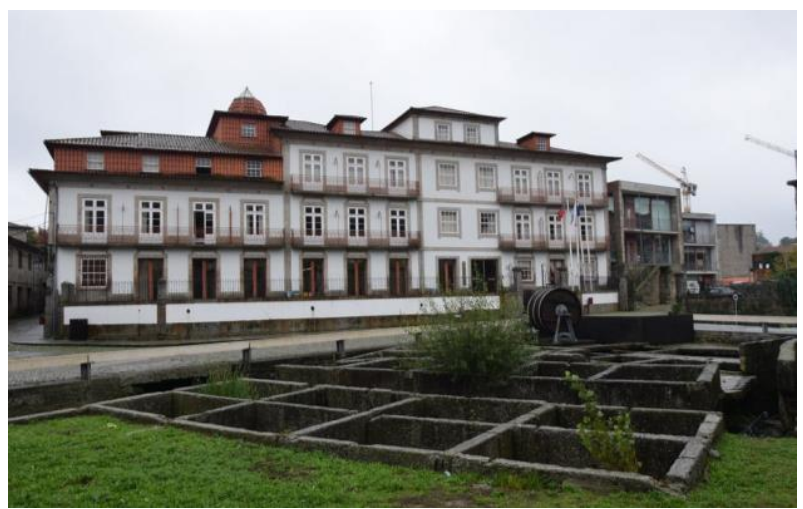

Figure 9. Main front views of Student Residence.
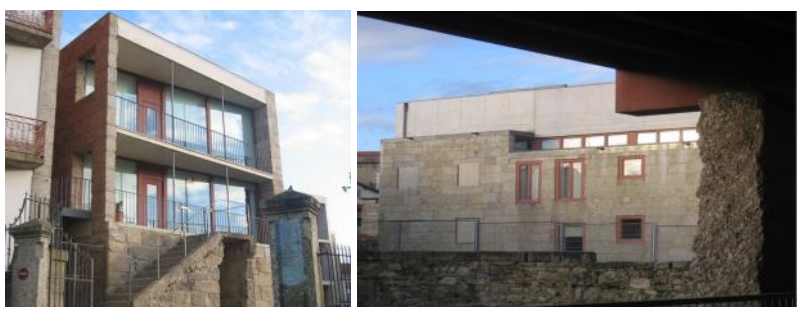

Figures 10 and 11. Fraterna Communication and Social Solidarity Centre / Multifunctional Couros Complex. Source: Author. 
Access to the Fraterna Communication and Social Solidarity Centre is through the front of the old leather tanks, which are in their original state (Figure 12).
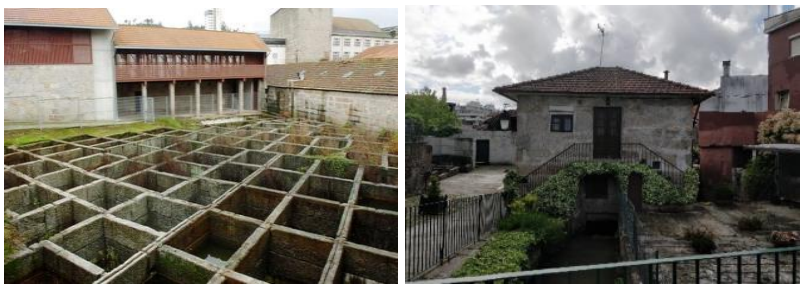

Figure 12. Left: view from Fraterna to the leather tanks. Source: Author.

Figure 13. Right: frontal view of Student Residence from the road, and former workers' houses crossing the Couros River. Source: Author

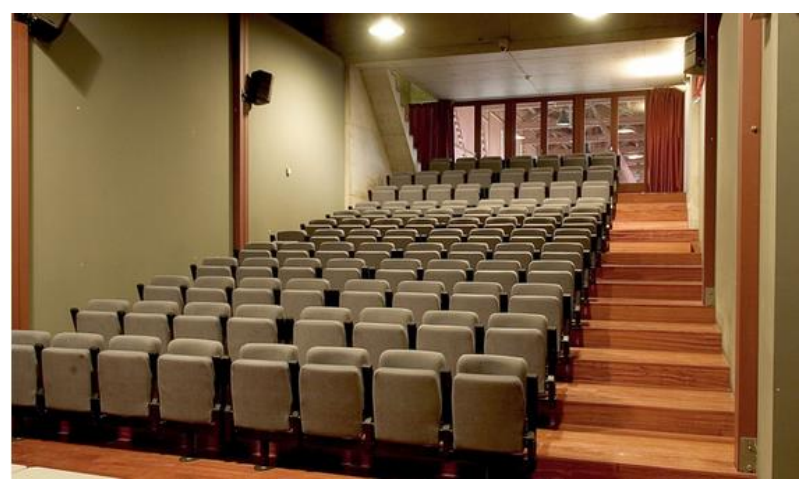

Figure 14. The Fraterna auditorium. Source: Author.
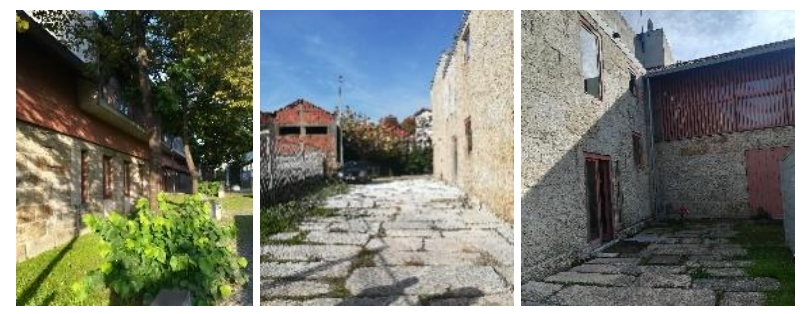

Figure 15. Series of images of the current state of the Multifunctional Couros Complex. Source: Author.

\subsection{Case study 2}

The analysis sheet of the former tannery factory shows its different uses over time and that the form of its spaces was essentially maintained. Its position in relation to the direction of the leather tanks is proof of its former industrial use and contributes to the generation of a collective memory of the events which took place there.

This project was originally set up by the University of Minho, focusing on the training of teachers and doctoral candidates, and well-known for its research spaces in privileged off-campus and central locations.

The set of buildings used for CAFPG - UM is located west of the large inner courtyard and was successively adapted to the needs of textile production but were unequally conserved. In the area now occupied by the CAFPG (Figure 16) buildings had been drastically transformed, either in terms of construction (introducing structures into reinforced concrete and brick walls) or spatially (introducing new levels and access), which made it virtually impossible to ascertain its original condition.

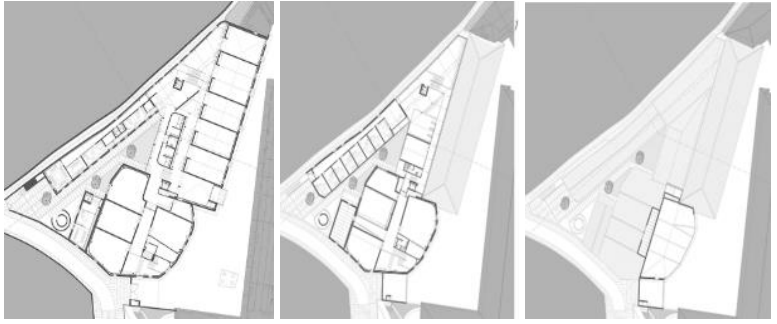

Figure 16. Architectural plans floor 1, 2 and 3 - occupied area for each floor and the increase of levels in the new proposal. Source: Revista Arquitectura \& Vida 01-02-2007, pp 37-38.

This renovation proposal aims to give life to a disfigured and aesthetically unappealing building. In order to improve its appeal architects carried out a series of actions with more flexible options, a less rigid approach, a pragmatic and detailed response to the problems faced by the project. Diagrams showcased the progress of this reinvention.

In general, the demolition of some interior areas was proposed, to be replaced by original constructive solutions such as brick walls and the complete demolition of existing structures in reinforced concrete. The volumes are maintained and conserved.

The material elements used are characteristic of Couros factories and include wood and granite finishes, light construction systems, and copper finishes on the ceilings, all major features of these constructions. Contemporary materials were used internally in order to guarantee comfort standards.

In this Centre for Advanced Post-graduate Formation, Universidad do Minho holds classes and activities, workshops and laboratories, as well as training courses. It is a space where the old architecture and the history of the place appear in contrast with the new use.

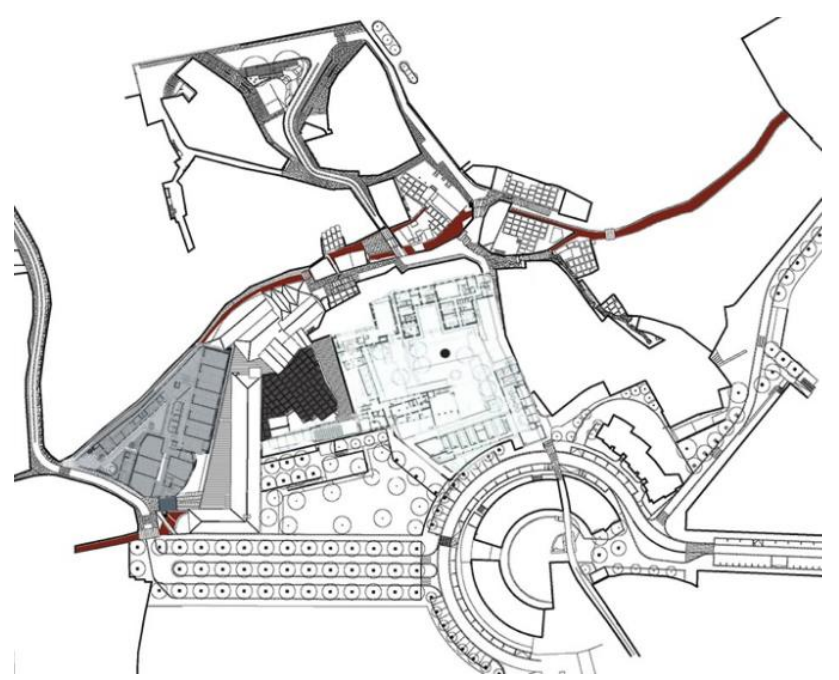

Figure 17. General location plan, Currently Centre for Advanced Post-graduate Formation, Universidad do Minho and

Multifunctional Couros Complex, with the river Couros shown in red, Guimarâes, Portugal. Design Group of architects Pitagoras. Source: Pitagoras Group.

The building has two floors and recreational roof spaces reserved for use as a technical area. The ground floor is made up of a communal room, teaching areas (classrooms) and an administrative area. Offices, laboratories, and activity rooms are located on the first floor, as is the library, although a search is 
underway for a more suitable location for this as it is too close to the social areas (Figures 18, 19, and 20). The circulation areas have an irregular geometry designed to provide more space for what are known as "living laboratories".
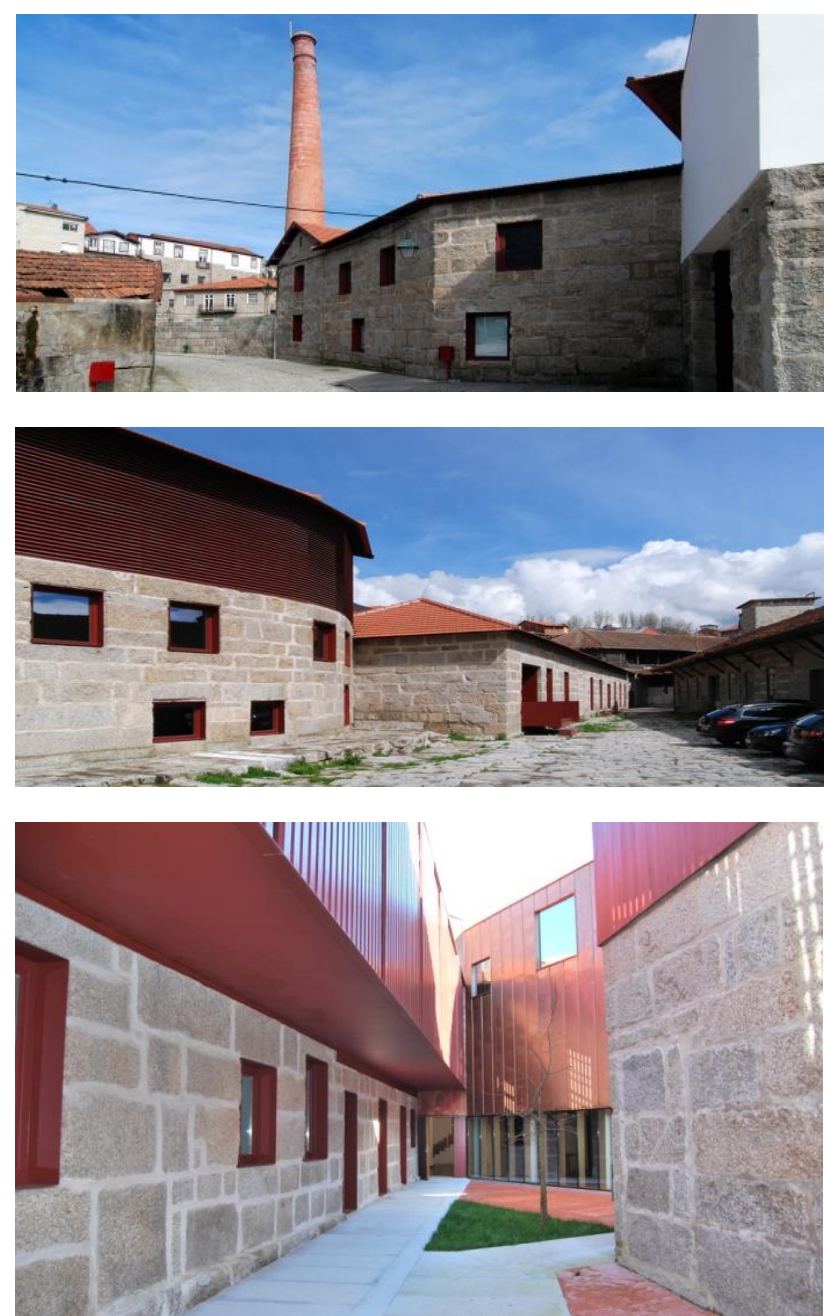

Figure 18, 19, and 20. Centre for Advanced Post-graduate Formation, Universidad do Minho Source: Author.

\section{CONCLUSIONS}

When analysing the two factories located on the river Couros, it was possible to see how the river begins its recovery and how the history of these old tanneries is showcased thanks to the pedestrian paths serving as a tourist corridor and found among the streets that border the projects.

The strategic location of these two factories on the Couros river and in the city centre encouraged economic activity at the time, and now its rehabilitation generates a positive impact on the tourism, educational and social sectors.

It is important to find the type of actions in these industries which have been carried out for re-using and rehabilitation in order to see industrial heritage with new eyes, other than those of history and collective memory.

At the end of the analysis of the morphological similarities of before and after in the two factories, the formal volume is preserved, showing the characteristic heritage elements, while their interiors become well-lit active spaces positively reflecting the rehabilitation.
The concept of sustainability is reflected in the rehabilitation of these two industrial buildings, since their useful life is extended, without abandoning the buildings, thus regenerating the urban landscape of the city.

\section{REFERENCES}

Cordeiro, J.M, 1998. La arquitectura industrial en Portugal. Ábaco 2 Epoca, No 19, Arqueología industrial. Testimonios de la memoria, pp. 35-44.

Cordeiro, J. M, 1996. A Industria de curtumes em Guimarâes, (sécs. XIX-XX), Actas do II Congresso Histórico de Guimarâes, Guimaräes, ed. Câmara Municipal de Guimarâes, Vol. IV.

Da Silva R. M, 2009. (Des) construir o vazio : coabitar o passado e o presente no sítio histórico de Guimarães, Tese mestrado, Arquitectura, Escola de Arquitectura da Universidade do Minho.

De Sousa Pinto, M, E. 2012. Os «Homens de Couros»: marcas no presente do passado da indústria de curtumes em Guimarães, Universidade do Minho, CITCEM «História das Populações».

Del Pozo, P. B, 2014. Dinamización del territorio y patrimonio industrial. Polígonos. Revista de Geografía, (7), p.p 123-131.

Domingues, C., Matos, D, 2011. Património e tecnicas de interpretación centro histórico de Guimarâes. Tese de mestrado, em turismo, inovaçao e desenvolvimiento, Politécnico de Viana do Castelo.

Folder of the local archive, in: Casa de Sarmento, Arquivo da Agência Portuguesa do Ambiente - ARH do Norte, Processo de Obras n. ${ }^{\circ} 1119-1950$, fl. 25.

Folder of the local archive, in: Casa de Sarmento, Arquivo da Agência Portuguesa do Ambiente ARH do Norte, Processo de Obras n. ${ }^{\circ}$ 291-1960 fl.6.

Meissner, H. G. 1993. La reconversión de la cuenca del Ruhr: un experimento y su valoración

Neves, J. A, das 1814. "Mapa Geral Estatistico que representa as Fábricas do Reino no estado em que existiam nos primeiros tempos depois da última invasâo; Obras completas, Porto Ediçoes Afrontamento, s/d, Volume 3, pp 239-271.

Pereira, R. A. 2009. Centro histórico de Guimarães : perspectivas de desenvolvimento, Guimarães : [s.n.],. - 65 f. : il. ; $30 \mathrm{~cm}$. - Relatório de projecto individual da Licenciatura em Engenharia Civil, apresentado à Universidade do Minho

Pinto, E. 2012, Curtidores e surradores de S. Sebastião Guimarães: (1865-1923) ; a difícil sobrevivência de uma indústria insalubre no meio urbano. Self-published with the help of Centro de Investigação Transdisciplinar Cultura, Espaço e Memória.

Pinto, M. E. S., Freitas, D., \& Almeida, C. 2002. Curtidores e Surradores de S. Sebastião (1865-1923): a difícil sobrevivência de uma indústria insalubre no meio urbano, Universidade do Minho, Braga.

Rodrigues, B. F., 2012.: Reabilitação de edifícios habitacionais com valor patrimonial: o caso do centro histórico de Guimarães. Master's thesis. Porto. 